\title{
Nephroselmis viridis (Nephroselmidophyceae, Chlorophyta), a new record for the Atlantic Ocean based on molecular phylogeny and ultrastructure
}

Karoline Magalhães Ferreira Lubiana ${ }^{1 *}$, Sônia Maria Flores Gianesella² ${ }^{2}$ Flávia Marisa Prado Saldanha-Corrêa ${ }^{2}$ and Mariana Cabral Oliveira ${ }^{1}$

\begin{abstract}
Nephroselmis is composed by unicellular nanoplanktonic organisms, occurring predominantly in marine environments. Currently, 14 species are taxonomically accepted. Nephroselmis viridis was described in 2011 and strains were isolated from Indic and Pacific Oceans. Since then, it was not recorded in other places. A strain was isolated from coastal waters of Brazil by micropipetting and washing, and cultivated in f/2 medium for morphological observations (light, confocal, SEM and TEM) and molecular phylogeny inferences (maximum likelihood and Bayesian). The cells are asymmetrical, have two unequal flagella, one cup-shaped chloroplast with an eyespot, and a large starch covered pyrenoid. Chloroplast thylakoids intrude into the pyrenoid and organic scales cover all cell body and flagella. Molecular phylogeny (18S rRNA) clustered the isolated strain with other Nephroselmis viridis sequences, and the species is the sister of the $N$. olivacea, the type species of the genus. Morphology and molecular phylogeny corroborate the strain identification, and it is the first time this species is recorded in Brazil and in the Atlantic Ocean.
\end{abstract}

Keywords: Brazilian coast, $18 \mathrm{~S}$ rRNA, Strain isolation, Morphology, Biodiversity

\section{Background}

Nephroselmis was described in 1879 by the typification of Nephroselmis olivacea Stein, and initially was allocated into Cryptophyceae (Parke and Rayns 1964). Further studies moved it to Chlorophyta, and Bourelly, in 1970, classified it as Prasinophyceae (Norris 1980). In the last decades, many studies taking into account molecular phylogeny have shown that Prasinophyceae is not monophyletic (Marin and Melkonian 2010; Marin and Melkonian 1994; Nakayama et al. 1998; Steinkotter et al. 1994). Hence, the class Nephroselmidophyceae (Nephrophyceae) was proposed to accommodate the genus (Cavalier-Smith 1993; Nakayama et al. 2007). This class seems to be an early derived clade of the core Chlorophyta (Daugbjerg et al. 1995;

\footnotetext{
* Correspondence: karolinemfl@usp.br

'Laboratório de Algas Marinhas "Édson José de Paula", Departamento de Botânica, Instituto de Biociências, Universidade de São Paulo, Rua do Matão 277, São Paulo, SP CEP 05508-090, Brazil

Full list of author information is available at the end of the article
}

Nakayama et al. 1998; Steinkotter et al. 1994; Turmel et al. 2009; Turmel et al. 1999), keeping a high number of ancestral characters.

Currently, 14 species of Nephroselmis are taxonomically accepted (Guiry and Guiry 2016), and except for $N$. olivacea which is freshwater, all other species are brackish or marine. The nuclear gene coding for the ribosomal small subunit RNA (18S rDNA) is the most widely used molecular marker for this group (Bell 2008; Faria et al. 2012; Faria et al. 2011; Nakayama et al. 2007; Nakayama et al. 1998; Yamaguchi et al. 2011). However, sequences for just nine species of this molecular marker are available in Genbank, representing less than $65 \%$ of the genus biodiversity.

Nephroselmis viridis Inouye, Pienaar, Suda \& Chihara was described in 2011 and strains were isolated from marine waters of Fiji, Japan and South Africa, in the Pacific and Indic Oceans (Yamaguchi et al. 2011). In the Atlantic Ocean, just five Nephroselmis species were 
recorded previously, vis., $N$. discoidea Skuja (Menezes and Bicudo 2008), N. fissa (Lackey 1940), N. minuta (N.Carter) Butcher (Butcher 1959; Domingos and Menezes 1998), N. pyriformis (N.Carter) Ettl (Bergesch et al. 2008; Moestrup 1983; Steinkotter et al. 1994), and N. rotunda (N.Carter) Fott (Bell 2008; Butcher 1959). Therefore, here we report for the first time the occurrence of $N$. viridis in Atlantic Ocean, isolated from the coast of Brazil, identified by molecular and microscopy tools.

\section{Methods}

\section{Strain isolation and culturing conditions}

The strain was isolated from a water sample collected in coastal area of Ubatuba, São Paulo, Brazil, close to Anchieta Island $\left(23^{\circ} 35.847^{\prime} \mathrm{S}, 45^{\circ} 01.70^{\prime} \mathrm{W}\right)$, at a depth of $40 \mathrm{~m}$. In the laboratory, a drop of the water sample was used to select the cell, which was transferred successively to sterile sea water drops until just the desired cell was present. Then, the cell was placed in $3 \mathrm{ml}$ of medium, and after 1 month transferred to higher volume. The isolated strain is being maintained in $\mathrm{f} / 2$ medium (without Si stock solution) (Guillard and Ryther 1962), salinity 32-35, temperature $20{ }^{\circ} \mathrm{C}( \pm 1)$, photoperiod of $12 \mathrm{~h}$ light/12 h dark, and $80 \mu \mathrm{E} \mathrm{m} \mathrm{m}^{-2} \cdot \mathrm{s}^{-1}$ radiation. The strain is deposited in the Microorganisms Collection Aidar \& Kutner from Oceanographic Institute, University of São Paulo (strain number BMAK193).

\section{Morphological characterization}

Cultures of 1-3 weeks old were used for morphological observations. Living and fixed cells ( $2 \%$ glutaraldehyde) were observed under light microcopy Leica DM 4000 B (Leica Microsystems, Wentzler, Germany), and confocal microscopy Zeiss LSM 440 Axiovent 100 (lp870/543 nm) (Carl Zeiss, Jena, Germany). For SEM and TEM, cultures were harvested by centrifugation ( $3 \mathrm{~min}, 100-150 \mathrm{~g}$ ), and transferred for $90 \mathrm{~min}$ to a fixative solution (2\% glutaraldehyde plus sodium cacodylate trihydrate $0.1 \mathrm{M}$, and sucrose $0.8 \mathrm{M}$ buffer). For the SEM preparation, cells were washed in cacodylate plus-sucrose buffer, and then post-fixed in osmium tetroxide (1\%) for $60 \mathrm{~min}$. After that, the cells were washed again in buffer, and dehydrated in an ethanol series (70, 90, 95 and 100\%). Finally, the sample was dried to critical point (Balzers CPD 030, Bal-Tec, Vaduz, Liechtenstein) and gold-coated (Balzers SCD 050) for visualization in Zeiss Sigma VP. For TEM, cells were dehydrated in an acetone series (50, 70, 95 and 100\%), and after embed in Spurr resin. Lastly, thin sectioned, stained, and observed in Zeiss EM 900.

DNA extraction, amplification, sequencing and molecular phylogeny

Genomic DNA was extracted using NucleoSpin ${ }^{\circ}$ Plant II kit (Macherey-Nagel, Düren, Germany), according to the manufactures instructions. PCRs of $18 \mathrm{~S}$ (small ribosomal subunit), ITS 1 and 2 (internal transcribed spacers), 5.8S and partial 28S (large ribosomal subunit) rRNA were amplified with Platinum ${ }^{\circ}$ Taq DNA polymerase kit (Invi$\operatorname{trogen}^{\mathrm{Tu}}$, Carlsbad, USA) and purified with the GFX Illustra kit (GE Healthcare Life Sciences, Little Chalfont, Buckinghamshire, UK), both done in accordance with the manufactures instructions. PCRs programs and primers are available as Additional file 1. Terminator Cycle Sequencing Ready Reaction kit (Applied Biosystems ${ }^{\mathrm{Tn}}$, Hammonton, NJ, USA) was used for sequencing reactions, and samples were sequenced using a 3730 DNA Analyzer (Applied Biosystems $\mathrm{s}^{\mathrm{Tu}}$, Hammonton, NJ, USA).

Sequences were assembled with Sequencher 4.7 software (Gene Codes Corporation, Ann Arbor, Michigan, USA), and were used to seek for other sequences in GenBank database. Thirty-four sequences were used in the matrix data (see Additional file 2). Four sequences of phylogenetically close species were used to root the tree (Pyramimonas aurea, Pseudoscourfieldia marina, and Pycnococcus provasolii). These sequences were chosen based on previous studies of Nephroselmis phylogeny (Faria et al. 2012; Faria et al. 2011; Nakayama et al. 2007; Yamaguchi et al. 2011). Introns were removed from the data. Dataset alignment was performed in AliView (Larsson 2014), using the Muscle algorithm (Edgar 2004). The appropriate evolution method was selected according to JModelTest 2.1.7 analysis (Darriba et al. 2012). Maximum likelihood (ML) phylogeny inference was performed in Garli (Bazinet et al. 2014) using 1000 bootstrap replicates (Felsenstein 1985), and two searches per run. MrBayes (Ronquist et al. 2012) was used to perform Bayesian analysis, with nodes confidence supported by posterior probability. Two runs were done consecutively, each one with $4 \times 10^{6}$ generations, four chains, and sampling at 100 generations. MrBayes generated $8 \times 10^{4}$ trees, whereas $6 \times 10^{4}$ were used to build the consensus tree (burn-in $2 \times 10^{4}$ ).

\section{Results}

\section{SYSTEMATICS}

\section{Order NEPHROSELMIDALES \\ Family NEPHROSELMIDACEAE \\ Genus Nephroselmis Stein 1878 \\ Nephroselmis viridis Inouye, Pienaar, Suda \& Chihara, 2011 (Fig. 1 and Yamaguchi et al. 2011)}

\section{Description}

The cells decant on the flasks bottom and the color of the culture is green in exponential phase and become olive in stationary and senescent phases. Cells are flattened when observed in ventral view and almost symmetrical in lateral 

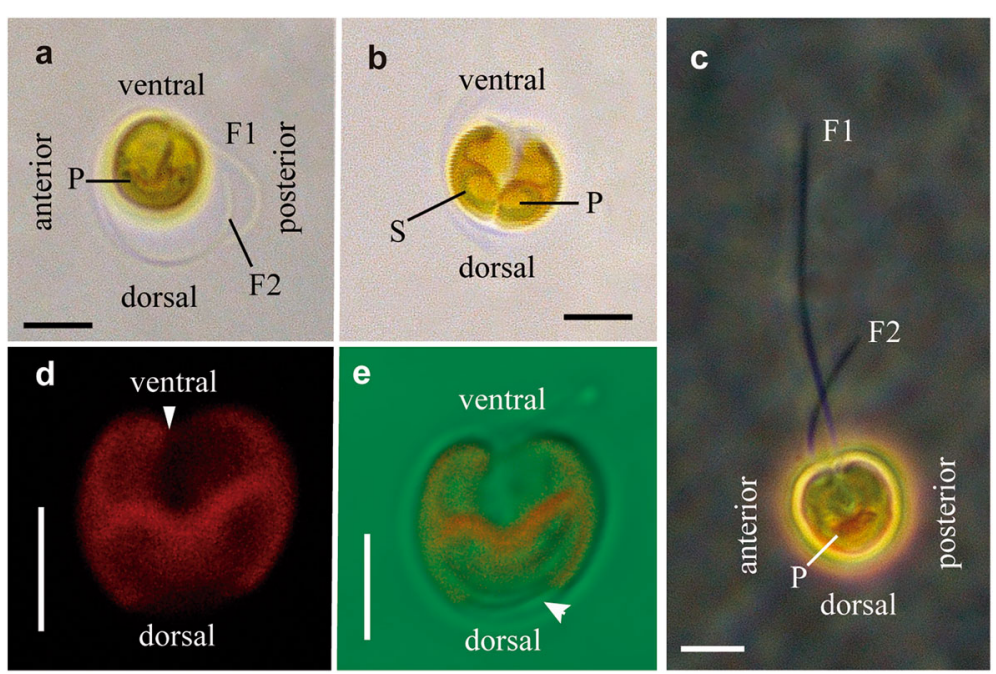

Fig. 1 Nephroselmis viridis morphology by light and confocal microscopy. Scale bars represents $5 \mu \mathrm{m}$. a Living cell in bright field coiling the flagella around the body; $\mathbf{b}$ Living cell in duplication observed in bright field. $\mathbf{c}$ Fixed cell in phase contrast evidencing the flagella length and pyrenoid. d Chloroplast natural fluorescence evidencing the chloroplast sinus (arrow) and pyrenoid. e Chloroplast fluorescence and cell morphology showing disk-like structure (arrow). (F1) longer flagellum, (F2) shorter flagellum, (P) pyrenoid. (S) starch sheath
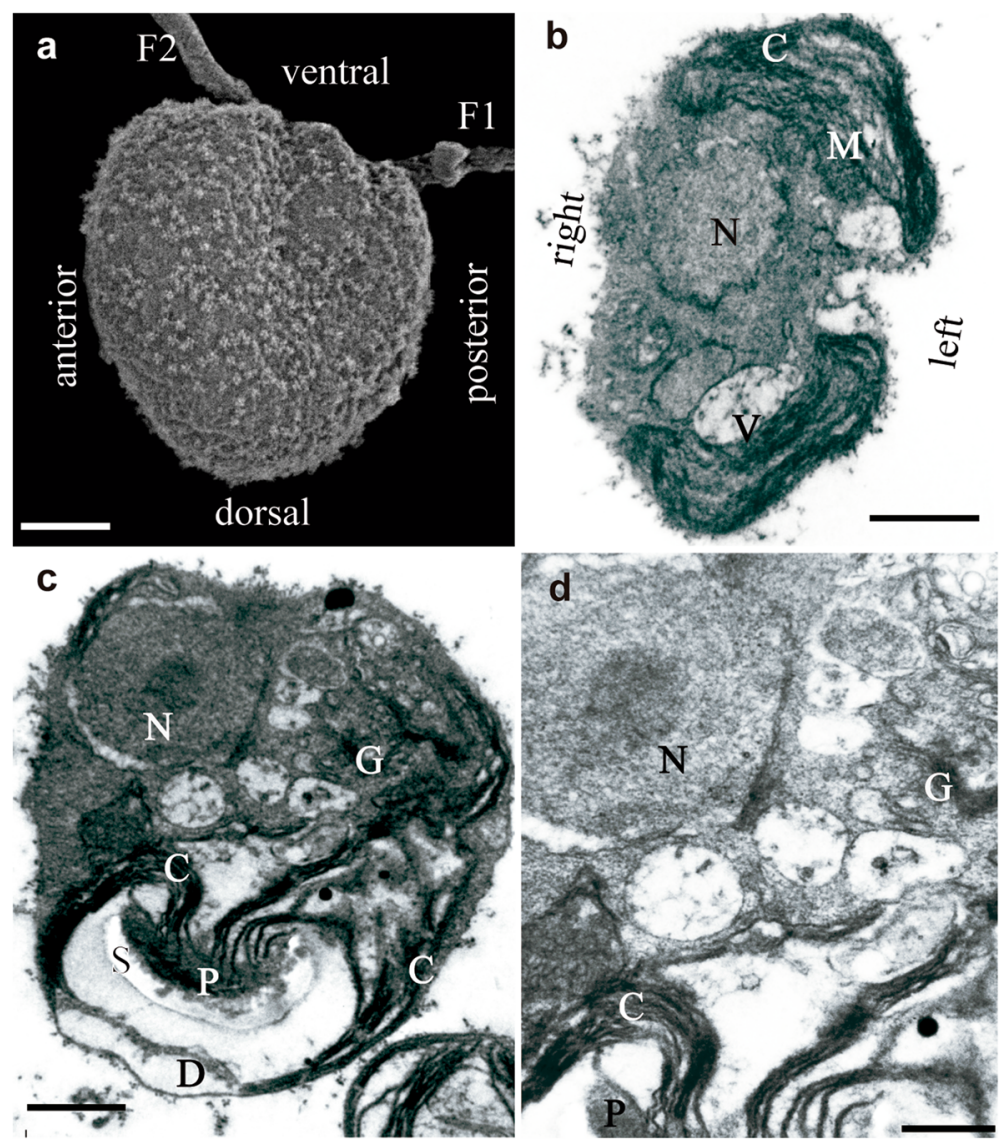

Fig. 2 Nephroselmis viridis morphology by electron microscopy. a SEM image showing cell surface and organic scales (Scale bar 1 m). b TEM image of the ventral view a cell showing the right nucleus (Scale bar $1 \mu \mathrm{m}$ ). c TEM image form the right- anterior view evidencing the organellar placement (Scale bar $1 \mu \mathrm{m}$ ). d More detailed view of organellar arrangement (Scale bar $0.5 \mu \mathrm{m})$. (C) chloroplast, (D) disk-like structure, (F1) longer flagellum, (F2) shorter flagellum, (G) Golgi body, (M) mitochondria, (N) nucleus, (P) pyrenoid. (S) starch sheath, and $(V)$ vacuoles 
view, bean-shaped, ranging 5 to $7.5 \mu \mathrm{m}$ in length and 5.5 to $9 \mu \mathrm{m}$ width (Figs. 1 and 2). During the cellular cycle, cells enlarge becoming more rounded, and the first noticeable feature is the expansion of the pyrenoid. The cells reproduce by bisection in the longitudinal axis (Fig. 1b), and sexual reproduction was not observed. Two unequal heterodynamic flagella emerge from a frontal groove, ventrally located (Figs. 1a, c and 2a). The bigger flagellum (F1), ranged from 20 to $27 \mu \mathrm{m}(3-4 \times)$, and the smaller flagellum (F2), ranged between 8.5 and $11.5 \mu \mathrm{m}(1-1.5 \times)$ (Fig. 1d). The cells commonly coil both flagella around the body when resting (Fig. 1a). An unique green parietal cup-shaped chloroplast was located at cells dorsal face (Figs. 1a, c, d, e and 2c) which has an eyespot in the anterior/ventral face (not show in figures). The chloroplast has a large sinus in the ventral portion (Fig. 1d), and a big cup-shaped pyrenoid starch sheath is at the dorsal region (Figs. 1b, c and 2c). Thylakoids sheets penetrate the pyrenoid (Fig. 2c). A disclike structure is located at the dorsal part of the cell (Figs. 1e and 2c). The nucleus is located in the right position, near the ventral face (Fig. $2 \mathrm{~b}$ and c). A single reticulate mitochondrion (Fig. 2b) is situated in the inner part of the chloroplast cavity, and a high number of Golgi vesicles are visible (Fig. 2c and d).

\section{Molecular phylogeny}

The $18 \mathrm{~S}$ rDNA of BMAK193 does not have introns. The sequences of ITS 1 and 2, 5.8S, and partial 28S rRNA obtained in this work were not used to infer phylogeny, due to few sequences of these markers in the Genbank

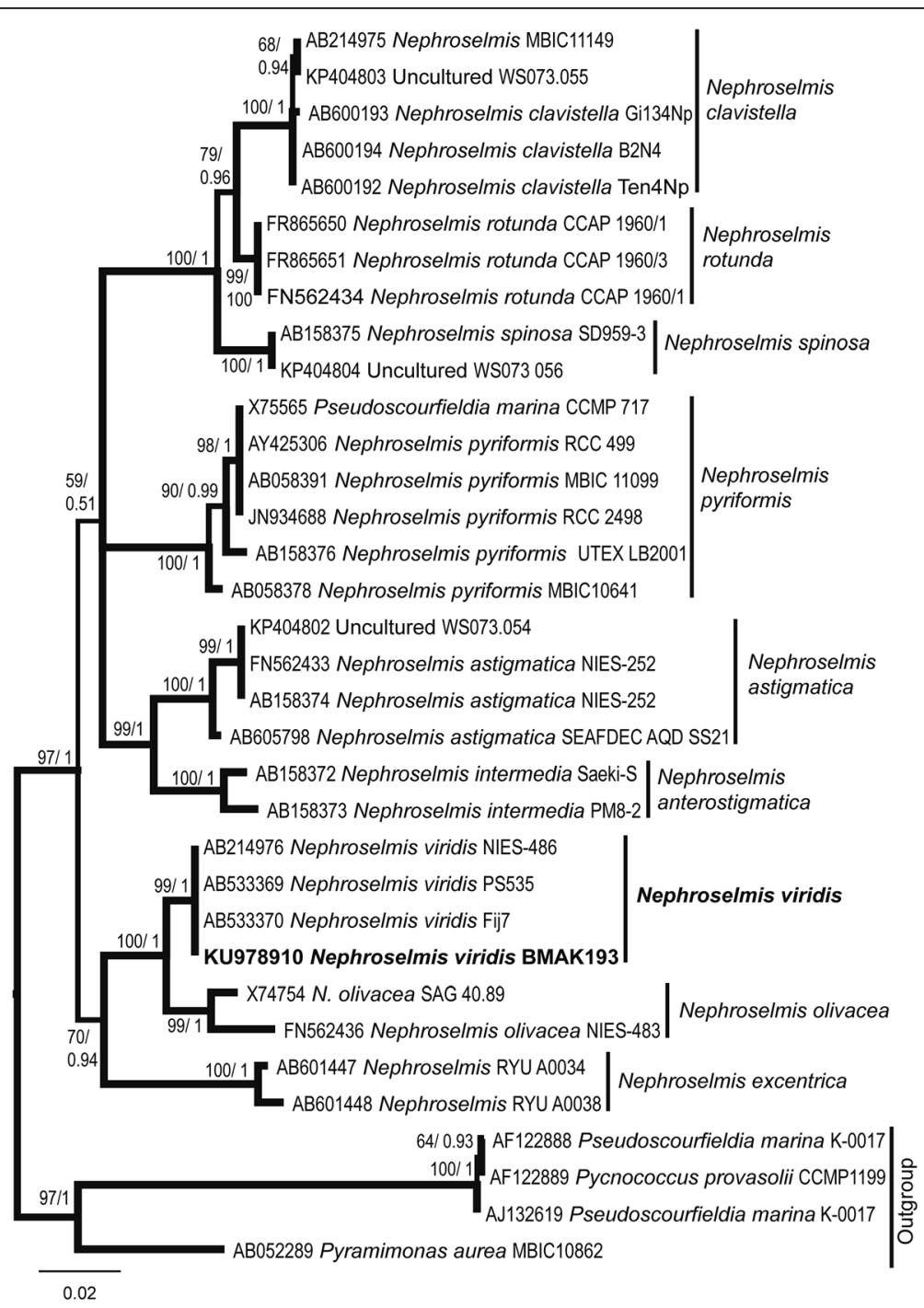

Fig. 3 Nephroselmis maximum likelihood phylogeny tree inferred by $18 \mathrm{~S}$ rRNA performed with 1000 bootstraps replicates in two consecutive runs. General time reversible with invariant sites $(I=0.6902)$ and gamma distribution rate $(\alpha=0.6101)$ was the evolutionary substitution nucleotide model used (GTR $+G+I$, InL -5465.48501). Nodes supports are bootstrap/posterior probability. Branch width represents the node bootstrap support. Scale bar is the rate of nucleotide substitution per site 
for the genus and the absence for the species. In the alignment matrix of $18 \mathrm{~S}$ rDNA, Nephroselmis viridis strains sequences are $100 \%$ identical (DNA matrix is available upon request). Maximum likelihood and Bayesian phylogenetic analysis clustered BMAK193 into Nephroselmis viridis strains (Fig. 3). It also pointed out that Nephroselmis is a monophyletic genus, and $N$. viridis is the sister group of the freshwater species $N$. olivacea.

\section{Discussion}

The cell measures of Nephroselmis viridis from the Atlantic Ocean, such as width and length of cell body and flagella, are exactly the same of the type described in Yamaguchi et al. (2011). Ultrastructural features observed also endorse the identification, such as the chloroplast form and location, the pyrenoid cup shaped and its starch sheath, the thylakoid sheets penetrating into the pyrenoid, the disk like structure, and the positions of the reticulate mitochondrion, nucleus, and Golgi apparatus. The shape and location of these organelles are the same as observed by Yamaguchi et al. (2011). However, the color of the cells and culture are different from the species description. The isolated strain is olive when in stationary and senescent physiological culture stage, different from the green color of the type.

The most common cell shape in Nephroselmis species is bean-shaped or semicircular, and symmetrical in anterior/ posterior and right/left axis, as in $N$ viridis (Faria et al. 2012; Faria et al. 2011; Yamaguchi et al. 2011). The cell and flagella size are overlapping in some Nephroselmis species. Another common feature widespread in this genus is coiling the flagella around the cell body when cells are resting (Faria et al. 2012; Faria et al. 2011; Suda 2003; Yamaguchi et al. 2011). For these reasons, N. viridis could be easily mistaken with $N$. rotunda in light microscopy investigation. Therefore, for reliable morphological identification ultrastructural information is need.

Molecular markers are more suitable for identification of species, once are less affected by erroneous or incomplete observations and morphological plasticity. The clustering of Nephroselmis viridis isolated from coastal waters of Brazil with other $N$. virids strains from Japan, Fiji and South Africa give a clear evidence that they are the same species. The $18 \mathrm{~S}$ rDNA pointed out that Nephroselmis is a monophyletic genus, and $N$. viridis is the sister group of the freshwater species $N$. olivacea, as observed in previous studies (Faria et al. 2012; Faria et al. 2011; Marin and Melkonian 2010; Yamaguchi et al. 2011; Yoshii et al. 2005). The $18 \mathrm{~S}$ rDNA of BMAK193 does not have introns, such as the strain isolated in Fiji (Fiji7). But, introns in the 18S rDNA are present in other two strains of $N$. viridis, NIES-486 and PS537, isolated from Japan (Yamaguchi et al. 2011).
Other species of Nephroselmis were detected in Brazilian coastal waters, such as $N$ discoidea (Menezes and Bicudo 2008), N. minuta, (Domingos and Menezes 1998), and N. pyriformis (Bergesch et al. 2008). However, most of the studies performed in South Atlantic Ocean investigate the composition of diatoms and dinoflagellates (Garcia and Odebrecht 2012; Jardim and Cardoso 2013; Lubiana and Dias Júnior 2016, and others). Consequently, the biodiversity status is rarely updated for other groups, such as the chlorophytes.

The small cell size, the challenge of morphological identification, and the species tendency to reside in sediments makes Nephroselmis viridis detection difficult. However, the species geographic distribution ought to be worldwide, especially in tropical and temperate marine regions (Yamaguchi et al. 2011), such as coastal waters of Brazil. Therefore, using an integrate methodology with culturing, morphological description, and molecular phylogeny we contribute to the knowledge of the biodiversity of the Atlantic Ocean, presenting the first record of Nephroselmis viridis in coastal waters of Brazil.

\section{Additional files}

Additional file 1: PCRs programs and primers used for amplification and sequencing. (DOC $67 \mathrm{~kb}$ )

Additional file 2: Sequences used from Genbank and their information. (DOCX $15 \mathrm{~kb}$ )

\section{Abbreviations}

SEM: Scanning electron microscopy; TEM: Transmission electron microscopy

\section{Acknowledgments}

We wish to thanks, André Nakasato, Willian da Silva Oliveira, and Rosario Petti for technical support. Also, Irwandro Pires and Waldir Caldeira from Electron Microscopy Laboratory of IB USP for the help with electron and confocal microscopes. Financial support was obtained from FAPESP (2010/ 50187-1), and CNPq scholarships to K. M. F. Lubiana (163070/2013-0), and to M.C. Oliveira (301491/2013-5).

\section{Funding}

FAPESP (2010/50 187-1), and CNPq scholarships to KMFL (163070/2013-0), and to MCO (301491/2013-5).

\section{Availability of data and materials}

The DNA sequence generated in this study are available in GENBANK repository, https://www.ncbi.nlm.nih.gov/genbank/. Reference number KU978910. The strain isolated in this study is available in Marine Microorganisms Collection Aydar \& Kutner, http://www.io.usp.br/index.php/ infraestrutura/banco-de-microorganismos. Reference number BMAK193. The sequence data matrix are available under request to corresponding author. Other data used in this publication are available in Additional files.

\section{Authors' contributions}

$\mathrm{KL}$ isolated the strain, obtained morphological and molecular data, and wrote the manuscript. SG assisted article composing. FSC did strain culturing for experiments. MCO draw the experiment, did the phylogenetic analysis, and assisted article composing. All authors read and approved the final manuscript.

Competing interests

The authors declare that they have no competing interests. 


\section{Consent for publication}

Not applicable.

\section{Ethics approval and consent to participate}

Not applicable.

\section{Author details}

"Laboratório de Algas Marinhas "Édson José de Paula", Departamento de Botânica, Instituto de Biociências, Universidade de São Paulo, Rua do Matão 277, São Paulo, SP CEP 05508-090, Brazil. ²Departamento de Oceanografia Biológica, Instituto Oceanográfico, Universidade de São Paulo, Praça do Oceanográfico, 191, São Paulo, SP CEP 05508-120, Brazil.

Received: 25 October 2016 Accepted: 19 January 2017 Published online: 02 February 2017

\section{References}

Bazinet AL, Zwickl DJ, Cummings MP. A gateway for phylogenetic analysis powered by grid computing featuring GARLI 2.0. Syst Biol. 2014;63(5):812-8.

Bell TG. A taxonomic and phylogenetic study of Nephroselmis Stein. 2008.

Bergesch M, Odebrecht C, Moestrup $\varnothing$. Nanoflagellates from coastal waters of southern Brazil (32º $)$. Bot Mar. 2008;51(1):35-50

Butcher RW. An introductory account of the smaller algae of British coastal waters. Part I: Introduction and Chlorophyceae. London; Fish Investig. 1959:4:1-74

Cavalier-Smith T. The origin, losses and gains of chloroplast. In: Lewin RE, editor Orig Plast Symbiogenes prochlorophytes Orig chloroplast. New York: Chapman and Hall; 1993. p. 291-48.

Darriba D, Taboada GL, Doallo R, Posada D. jModelTest 2: more models, new heuristics and parallel computing. Nat Methods. 2012;9(8):772.

Daugbjerg N, Moestrup $\varnothing$, Arctander P. Phylogeny of genera of Prasinophyceae and Pedinophyceae (Chlorophyta) deduced from molecular analysis of the rbcL gene. Phycol Res. 1995;43:203-13.

Domingos P, Menezes M. Taxonomic remarks on planktonic phytoflagellates in a hypertrophic tropical lagoon (Brazil). Hydrobiologia. 1998;369/370:297-313.

Edgar RC. MUSCLE: multiple sequence alignment with high accuracy and high throughput. Nucleic Acids Res. 2004;32(5):1792-7.

Faria DG, Kato A, de la Peña MR, Suda S. Taxonomy and phylogeny of Nephroselmis clavistella sp. nov. (Nephroselmidophyceae, Chlorophyta). J Phycol. 2011;47(6):1388-96.

Faria DG, Kato A, Suda S. Nephroselmis excentrica sp. nov. (Nephroselmidophyceae, Chlorophyta) from Okinawa-jima, Japan. Phycologia. 2012;51(3):271-82.

Felsenstein J. Confidence limits on phylogenies: an approach using bootstrap. Evolution. 1985;39(4):783-91.

Garcia M, Odebrecht C. Remarks on the morphology and distribution of some rare centric diatoms in southern Brazilian continental shelf and slope waters. Braz J Oceanogr. 2012;60(4):415-27.

Guillard RR, Ryther JH. Studies of marine planktonic diatoms. I. Cyclotella nana Hustedt, and Detonula confervacea (Cleve) Gran. Can J Microbiol. 1962:8:229-39.

Guiry MD, Guiry GM. AlgaeBase. World-wide eletronic Publ Natl Univ Ireland, Galw. 2016. http://www.algaebase.org. Accessed 2 Oct 2016.

Jardim PFG, de Cardoso LS. New distribution records of Dinophyta in Brazilian waters. Check List. 2013;9(3):631-9.

Lackey JB. Some new flagellates from the Woods Hole Area. Am Midl Nat. 1940 23(2):463-71.

Larsson A. Aliview: a fast and lightweight alignment viewer and editor for large datasets. Bioinformatics. 2014;30(22):3276-8.

Lubiana KMF, Dias Júnior $C$. The composition and new records of micro- and mesophytoplankton near the Vitória-Trindade Seamount Chain. Biota Neotrop. 2016;16(3):e20160164.

Marin B, Melkonian M. Flagellar hairs in Prasinophytes (Chlorophyta): ultrastructure and distribution on the flagellar surface. J Phycol. 1994; 30(4):659-78

Marin B, Melkonian M. Molecular phylogeny and classification of the Mamiellophyceae class. nov. (Chlorophyta) based on sequence comparisons of the nuclear- and plastid-encoded rrna operons. Protist. 2010;161(2):304-36.

Menezes M, Bicudo CEM. Flagellate green algae from four water bodies in the state of Rio de Janeiro. Southeast Brazil. Hoehnea. 2008;35(3):435-68.

Moestrup $\varnothing$. Further studies on Nephroselmis and its allies (Prasinophyceae). I. The question of the genus Bipedinomonas. Nord J Bot. 1983;3(1979):609-27.
Nakayama T, Marin B, Kranz HD, Surek B, Huss VAR. The basal position of scaly green flagellates among the green algae (Chlorophyta) is revealed by analyses of nuclear-encoded SSU rRNA sequences. Protist. 1998;149:367-80.

Nakayama T, Suda S, Kawachi M, Inouye I. Phylogeny and ultrastructure of Nephroselmis and Pseudoscourfieldia (Chlorophyta), including the description of Nephroselmis anterostigmatica sp. nov. and a proposal for the Nephroselmidales ord. nov. Phycologia. 2007;46:680-97.

Norris RE. Prasinophytes. In: Cox ER, editor. Phytoflagellates. New York: Elsevier; 1980. p. 85-146.

Parke M, Rayns DG. Studies on marine flagellates: VII Nephroselmis gilva sp nov. and some allied forms. J Mar Biol Ass UK. 1964:44:209-17.

Ronquist F, Teslenko M, Van Der Mark P, Ayres DL, Darling A, Höhna S, et al. Mrbayes 3.2: Efficient bayesian phylogenetic inference and model choice across a large model space. Syst Biol. 2012;61(3):539-42.

Steinkotter J, Bhattacharya D, Semmelroth I, Bibeau C, Melkonian M. Prasinophytes form independent lineages within the Chlorophyta: evidence from ribosomal RNA sequence comparations. J Phycol. 1994;30(2):340-5.

Suda S. Light microscopy and electron microscopy of Nephroselmis spinosa sp. nov. (Prasinophyceae, Chlorophyta). J Phycol. 2003;39(3):590-9.

Turmel M, Gagnon MC, O'Kelly CJ, Otis C, Lemieux C. The chloroplast genomes of the green algae Pyramimonas, Monomastix, and Pycnococcus shed new light on the evolutionary history of prasinophytes and the origin of the secondary chloroplasts of euglenids. Mol Biol Evol. 2009;26(3):631-48.

Turmel M, Otis C, Lemieux C. The complete chloroplast DNA sequence of the green alga Nephroselmis olivacea: insights into the architecture of ancestral chloroplast genomes. Proc Natl Acad Sci U S A. 1999;96(18):10248-53.

Yamaguchi H, Suda S, Nakayama T, Pienaar RN, Chihara M, Inouye I. Taxonomy of Nephroselmis viridis sp. nov. (Nephroselmidophyceae, Chlorophyta), a sister marine species to freshwater N. olivacea. J Plant Res. 2011;124(1):49-62.

Yoshii Y, Takaichi S, Maoka T, Suda S, Sekiguchi H, Nakayama T, et al. Variation of siphonaxanthin series among the genus Nephroselmis (Prasinophyceae, Chlorophyta), including a novel primary methoxy carotenoid. J Phycol. 2005:41(4):827-34.

\section{Submit your next manuscript to BioMed Central and we will help you at every step:}

- We accept pre-submission inquiries

- Our selector tool helps you to find the most relevant journal

- We provide round the clock customer support

- Convenient online submission

- Thorough peer review

- Inclusion in PubMed and all major indexing services

- Maximum visibility for your research

Submit your manuscript at www.biomedcentral.com/submit
C) Biomed Central 